\title{
Toxicological evaluation of the plant products using Brine Shrimp (Artemia salina L.) model
}

\author{
Mentor R. Hamidi, Blagica Jovanova, Tatjana Kadifkova Panovska* \\ Faculty of Pharmacy, Institute of Applied Biochemistry, Department of Toxicology, Ss. Cyril and Methodius University, \\ Majka Tereza 47, Skopje, Republic of Macedonia
}

Received: February 2014; Accepted: April 2014

\begin{abstract}
Many natural products could serve as the starting point in the development of modern medicines because of their numerous biological and pharmacological activities. However, some of them are known to carry toxicological properties as well. In order to achieve a safe treatment with plant products, numerous research studies have recently been focused on both pharmacology and toxicity of medicinal plants. Moreover, these studies employed efforts for alternative biological assays. Brine Shrimp Lethality Assay is the most convenient system for monitoring biological activities of various plant species. This method is very useful for preliminary assessment of toxicity of the plant extracts. Rapidness, simplicity and low requirements are several advantages of this assay. However, several conditions need to be completed, especially in the means of standardized experimental conditions (temperature, $\mathrm{pH}$ of the medium, salinity, aeration and light). The toxicity of herbal extracts using this assay has been determined in a concentration range of 10,100 and $1000 \mu \mathrm{g} / \mathrm{ml} \mathrm{of} \mathrm{the} \mathrm{examined} \mathrm{herbal} \mathrm{ex-}$ tract. Most toxicity studies which use the Brine Shrimp Lethality Assay determine the toxicity after 24 hours of exposure to the tested sample. The median lethal concentration $\left(\mathrm{LC}_{50}\right)$ of the test samples is obtained by a plot of percentage of the dead shrimps against the logarithm of the sample concentration. $\mathrm{LC}_{50}$ values are estimated using a probit regression analysis and compared with either Meyer's or Clarkson's toxicity criteria. Furthermore, the positive correlation between Meyer's toxicity scale for Artemia salina and Gosselin, Smith and Hodge's toxicity scale for higher animal models confirmed that the Brine Shrimp Lethality Assay is an excellent predictive tool for the toxic potential of plant extracts in humans.
\end{abstract}

Keywords: brine shrimp lethality assay; toxicity testing; plant extracts; probit analysis; $\mathrm{LC}_{50}$

\section{Introduction}

The search for new drugs which are plant-derived has been receiving renewed interest among researchers throughout the world in view of discovering new drugs that possess potency to combat the menace of drug resistant pathogenic microorganisms, antitumor and anticancer agents (Mirzaei and Mirzaei, 2013; Santos Pimenta et al., 2003).

Plants can be useful either in their crude or advanced forms, offering a source of drugs in their pure state (Farnsworth and Soejarto, 2009). According to the World Health

\footnotetext{
* Tel.: +389 23126024 ext. 201;

Fax: +38923123054

e-mail: taka@ff.ukim.edu.mk
}

Organization's questionnaire, it is announced that $70-80 \%$ of the population in the world are relying on unconventional medicine, mainly in plant sources, in the primary health protection (WHO, 2007). Recognized for their ability to produce a wealth of secondary metabolites, many of these natural products have been shown to present interesting biological and pharmacological activities, which could serve as the starting point in the development of modern medicines (Abubakar et al., 2010).

Well-known drugs which were developed from plant species are Vinblastine and Vincristine (first cures in human cancer) from Catharanthus roseus, Quinine (anti-malarial agent) from Cinchona species, Scopolamine (sedative) from Datura metel L., and many others which remained in use until present day (Farnsworth and Soejarto, 2009). 
Although many plants have valuable properties, some of them are known to carry toxicological properties as well. Recent studies indicate that although numerous plants are used as food sources, some of them may have mutagenic or genotoxic potential (Tülay and Özlem, 2007). Numerous research studies have recently focused on both pharmacology and toxicity of medicinal plants used by humans. This is of high importance in order to achieve a safe treatment with plant products (Parra et al., 2001).

The toxicity of the plants may originate from different contaminants or from plant chemical compounds that are part of the plant. Various assays are used for the research of potential toxicity of herbal extracts based on different biological models, such as in vivo assays on laboratory animals. However, recent studies employed efforts for alternative biological assays that include species of Artemia salina, Artemia franciscana, Artemia urmiana and Thamnocephalus platyurus. These toxicity tests are considered a useful tool for preliminary assessment of toxicity (Carballo et al., 2002; Veni and Pushpanathan, 2014; Mayorga et al., 2010).

During the past 30 years, the Brine Shrimp Assay has been widely used to test the toxicity of a great variety of plant products. Brine shrimp (A. salina) is most extensively studied of the Artemia species, estimated to represent over $90 \%$ of the studies in which Artemia is used as an experimental test organism (Campbell et al., 1994). The Brine Shrimp Toxicity Assay was proposed and developed by Michael et al. (1956) and later adapted by Vanhaecke et al. (1981), Meyer et al., (1982), and Sleet and Brendel (1983).

Brine Shrimp Lethality Assay (BSLA) has been applied as an alternative bioassay technique to screen the toxicity of plant extracts (Meyer et al., 1982; McLaughlin et al., 1998a; Moshi et al., 2010; Ogugu et al., 2012; Gadir, 2012; Solanki and Selvanayagam, 2013; Sharma et al., 2013), toxicity of heavy metals (Sleet and Brendel, 1985; Martínez et al., 1999) and metal ions (Kokkali et al., 2011), toxicity of cyanobacteria (Jaki et al., 1999) and algae (Mayorga et al., 2010), cytotoxicity of dental materials (Pelka et al., 2000), toxicity of nanoparticles (MaurerJones et al., 2013), as well as screening of marine natural products (Carballo et al., 2002).

The technique is economic and utilizes small amount of test material (Pisutthanan et al., 2004). Since its introduction, this in vivo test has been successively employed for bioassay-guide fractionation of active cytotoxic and antitumor agents (Ahmed et al., 2010; Ramachandran et al., 2011). Additionally, several studies demonstrated that there is a good correlation between the results for the lethal concentration that kills $50 \%$ of the exposed population $\left(\mathrm{LC}_{50}\right)$ obtained with the Brine Shrimp Lethality Assay using $A$. salina and the results of the Acute Oral Toxicity Assay in Mice (Parra et al., 2001; Arlsanyolu and Erdemgil, 2006).

\section{Plant collection, storage and preparation of herbal extracts}

Collected plant materials (root, bark, branches, stipules, leaves, flowers, fruits or whole plant) were authenticated by comparing with herbarium specimens. After identification, they were washed and dried before examination (Ogugu et al., 2012; Lalisan et al., 2014), either airdried or dried in an air stove to higher temperature ( 40 ${ }^{\circ} \mathrm{C}$ ) (Ahmed et al., 2010; Parra et al., 2001; Olowa and Nuñeza, 2013). All were chopped in a grinder mill and stored in desiccators at room temperature (Parra et al., 2001; Veni and Pushpanathan, 2014). For antimicrobial tests, the material was pulverized in sterile electric blender (Lalisan et al., 2014).

The powdered plant sample was soaked in one solvent or mixture of solvents for a longer period of time, either by using laboratory extraction flasks or Soxhlet extractor (Veni and Pushpanathan, 2014), followed by filtration and evaporation, concentrated to dryness under reduced pressure using rotary evaporator (Mayorga et al., 2010). Several other extraction techniques are repercolation with multiple extractions, maceration of the plant material or decoction of a fresh plant material over a period of time (Parra et al., 2001). Depending on the nature of the plant material, some steps of the extraction process were optional (for example, the Soxhlet extraction of plant samples has been employed in order to extract substances of low and medium volatility as well as thermally stable constituents based on polarity gradient of the solvent) (Veni and Pushpanathan, 2014).

Choosing the type of solvent for the extraction process is vital for the toxicity testing, because different solvents show different extracting potential. If possible, extraction should be carried out under mild conditions utilizing solvents of low reactivity (Ghisalberti, 1993). Methanol, $96 \%$ ethanol, n-hexane, ethyl acetate, petroleum ether, carbon tetrachloride, dichloromethane and acetone are the most commonly used extracting solvents for this purpose (Ahmed et al., 2010; Ogugu et al., 2012).

In case of air or freeze-dried samples, a polar solvent such as ethyl acetate or methanol is preferable. Alcoholic solvents rupture cell membranes and extract greater amount of endocellular materials, and in this case the separation of pure compounds is left for a later chromatographic separation (Arlsanyolu and Erdemgil, 2006; Ghisalberti, 1993).

If a mixture of solvents is a more suitable option for extraction of some compounds, then a good system with high extraction potential is a 1:1 mixture of two solvents, but the ratio highly depends on the preferred polarity of the mixture (Pimentel Montanher et al., 2002). In case of fresh plant materials, dichloromethane-methanol solvent mixture is ideal for extracting purposes. This is usually followed by re-extraction using less polar solvents in order to separate the lipophilic fraction from the water-soluble fraction (Ghisalberti, 1993). 
Studies have shown that there is a significant difference in the obtained $\mathrm{LC}_{50}$ results for different solvents' extracts, mainly because some solvents are a poor medium for obtaining specific bioactive components (responsible for the toxicity) from the plant sample, than others (Lalisan et al., 2014).

Dimethylsulfoxide is widely used solvent for the reconstitution of evaporated plant extracts, because brine shrimp nauplii show no significant sensitivity to this solvent up to $11 \%$ concentration (Ahmed et al., 2013; Musa, 2012; Kamba and Hassan, 2010). Preparation of stock solution and several dilutions (suggested by McLaughlin, 1991) provide different dose levels, which gives opportunity to determine the linear increase of the toxicity by increasing the concentration of the toxic compound(s) present in the plant extract.

\section{Advantages vs disadvantages of the Brine Shrimp Assay}

Brine Shrimp Lethality Assay is a convenient system for monitoring biological activities of various plant species. Although this method does not provide any adequate information regarding the mechanism of toxic action, it is a very useful method for the assessment of the toxic potential of various plant extracts (Gadir, 2012; Naidu et al., 2014). This method provides preliminary screening data that can be backed up by more specific bioassays once the active compounds have been isolated (Pisutthanan et al., 2004).

This test has several advantages which can be summarized as follows:

- Rapidness (the monitoring could be extended to maximum 60 hours, but in most cases, relevant data for the $\mathrm{LC}_{50}$ calculations are obtain after 24 hours of exposure),

- Simplicity (no special training needed for the equipment and the assay),

- Low requirements (no aseptic techniques, no special equipment, relatively small amount of test sample is needed and a large number of test organisms of exactly the same age and physiological condition can be easily obtained to start the test),

- Robustness (the cysts are commercially and readily available so that the tests can be carried out worldwide with the same original material and without any problem of provisioning),

- Inexpensiveness (the quantity of cysts required per test is very small so that the price of the biological material is negligible),

- High degrees of repeatability - according to ARC - test (Artemia Reference Centre) (Vanhaecke et al., 1981; Meyer et al., 1982; McLaughlin and Rogers, 1998b; Vanhaecke and Persoone, 1984).
Apart from the great number of advantages this method has, several criteria need to be completed in order to achieve a broad applicability of the Brine Shrimp Assay. This includes the following:

- Standardized experimental conditions in the means of temperature, salinity, aeration, light and $\mathrm{pH}$,

- Same geographical region of the cysts,

- Same age of Artemia nauplii at the start of every test,

- Positive and negative controls are essential part of the assay, in order to check the sensitivity of the larvae and the conformity with the standard procedure (Vanhaecke et al., 1981).

\section{Hatching of Artemia cysts}

The container used for brine shrimp hatching, consists of two unequal chambers with several holes on the divider in between (Fig.1). This will enable the hatched Artemia nauplii (Fig.2) to migrate from the hatching compartment into the illuminated compartment (Sharma et al., 2013; Pisutthanan et al., 2004). Both chambers of the container are filled with artificial sea water (3.8\%) (Gadir, 2012; Ogugu et al., 2012). In some Brine Shrimp Assays, the seawater might contain other salts such as $\mathrm{MgCl}_{2} \cdot 6 \mathrm{H}_{2} \mathrm{O}$, $\mathrm{Na}_{2} \mathrm{SO}_{4}, \mathrm{CaCl}_{2} \cdot 2 \mathrm{H}_{2} \mathrm{O}$ or $\mathrm{CaCl}_{2} \cdot 6 \mathrm{H}_{2} \mathrm{O}$ (Parra et al., 2001). After filtration through a $1 \mu \mathrm{m}$ filter under vacuum, the artificial sea water is ready for hatching of the Artemia cysts (Vanhaecke et al., 1981).

The container needs to be spacious enough to contain an air pump. Supplying a regular air flow with average pressure and proper light is essential for the hatching process (Veni and Pushpanathan, 2014; Mirzaei and Mirzaei, 2013). This is important because the artificial seawater should be at least $90 \%$ saturated with oxygen for a successful hatching (Vanhaecke et al., 1981). In addition, equal distribution of the oxygen in the seawater is achieved by a constant aeration and pressure in the solution for 48 hours in order to reach Artemia nauplii mature state.

Small quantities of dry cysts of Artemia salina were sprinkled into the dark, larger chamber. Yeast solution $0.06 \%$ was added to the hatching chamber for every liter of salt water to feed the larvae after 24 hours, otherwise the Artemia larvae would die during the III or IV instar stage (Parra et al., 2001; Sorgeloos et al., 1978). The molting into the further larval stages is dependent on temperature $\left(37^{\circ} \mathrm{C}\right)$ as well as quality and quantity of food (Lalisan et al., 2014). After 36 hours of incubation at room temperature $\left(22-29{ }^{\circ} \mathrm{C}\right)$, the active nauplii free from egg shells were attracted by the light source into the smaller chamber (Sharma et al., 2013; Pisutthanan et al., 2004). It is important that nauplii from the same generation are applied for each concentration of the tested compound (Ogugu et al., 2012). 


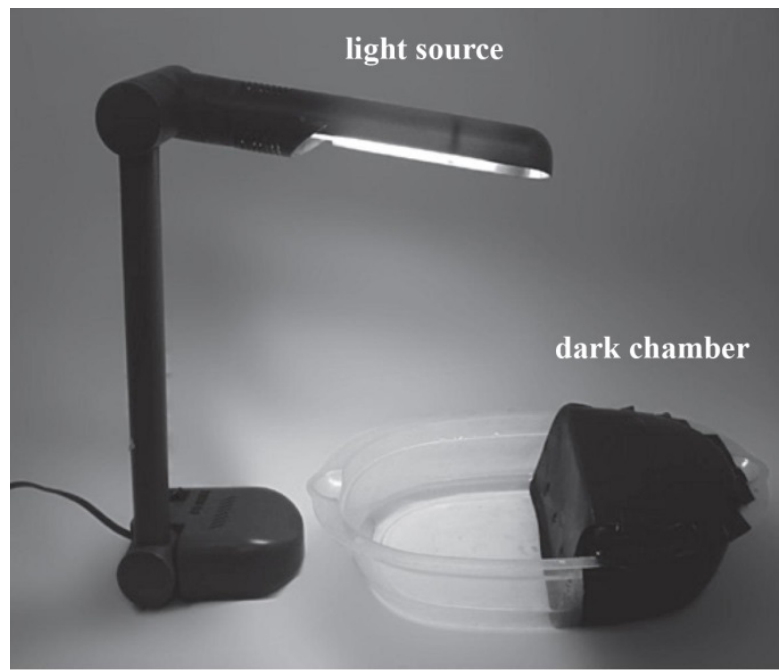

Fig. 1 Container used for hatching Artemia nauplii (Pellosi et al., 2013).

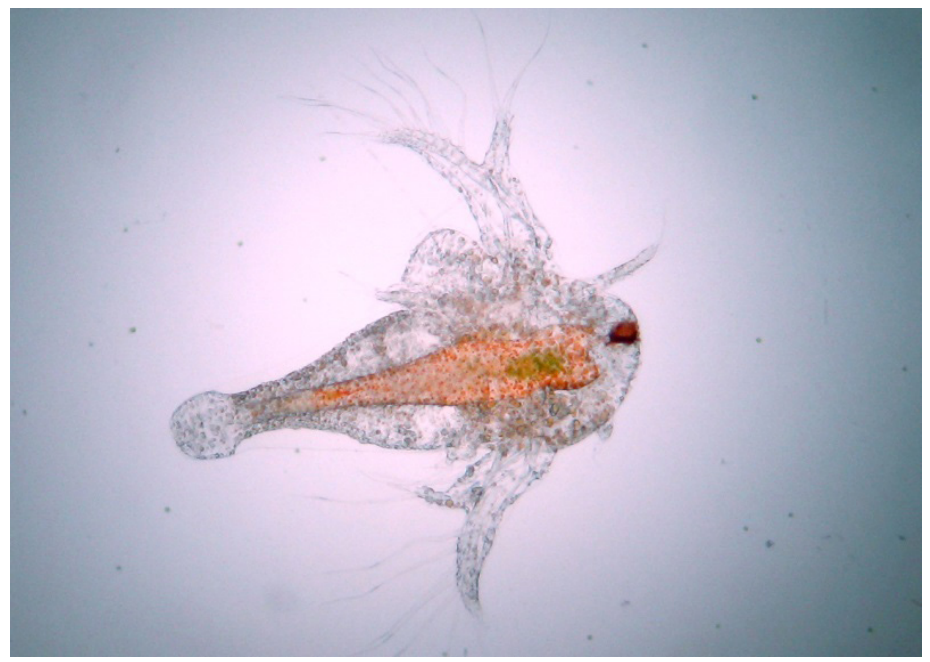

Fig. 2 Artemia salina nauplius (by Juan Camilo Jaramillo).

\section{Influence of the experimental conditions over the sensitivity of Artemia nauplii}

The $\mathrm{pH}$ value of the seawater is a very important factor for the hatching of the Artemia eggs. Optimal $\mathrm{pH}$ range is $8.0 \pm 0.5$. If necessary, the $\mathrm{pH}$ should be adjusted using $\mathrm{NaOH}$ or $\mathrm{Na}_{2} \mathrm{CO}_{3}$, to avoid lethality of the Artemia larvae caused by decrease of $\mathrm{pH}$ during incubation (Vanhaecke et al., 1981; Parra et al., 2001).

Temperature variations affect the hatching process of Artemia cysts. Warmer medium temperature enables faster hatching of the cysts (Table 1).

It has been shown that $50 \%$ of the cysts hatch within 30 hours at $20^{\circ} \mathrm{C}$, while at $24^{\circ} \mathrm{C}$ this percentage is already obtained after 21 hours. With regard to the molting rate, it appears that at $24{ }^{\circ} \mathrm{C}$ more than $60 \%$ of the larvae molt into the II instar stage 16 hours after hatching, whereas at $20{ }^{\circ} \mathrm{C}$ it takes 35 hours to arrive at the same stage (Sorgeloos et al., 1978).

The light stimulus influences the hatching of Artemia cysts significantly. Sorgeloos explained how the embryological development of hydrated embryos that are not stimulated by light, can be delayed until the light trigger is applied. Apparently, the cysts started hatching after being exposed to light, which gave statistically significant differences between the dark and the light series (Sorgeloos, 1973).

Additionally, Vanhaecke et al. (1981) indicated that the most sensitive age for the majority of the tested compounds were the 48 hour-old nauplii at the stage of instar II-III. 
Table 1. Percentage of hatched and molted cysts depending on the temperature of the medium*

\begin{tabular}{cccc}
\hline \hline $\begin{array}{c}\text { Temperature of the } \\
\text { medium }\end{array}$ & $\begin{array}{c}\text { Percentage of } \\
\text { hatched cysts }\end{array}$ & Hatching time & Developmental stage reached \\
\hline $20{ }^{\circ} \mathrm{C}$ & $50 \%$ & 30 hours & I (first) stage \\
$24{ }^{\circ} \mathrm{C}$ & $50 \%$ & 21 hours & I (first) stage \\
\hline \hline $\begin{array}{c}\text { Temperature of the } \\
\text { medium }\end{array}$ & $\begin{array}{c}\text { Percentage of molted } \\
\text { larvae }\end{array}$ & $\begin{array}{c}\text { Hatching time } \\
+ \\
\text { molting time }\end{array}$ & Developmental stage reached \\
\hline $20^{\circ} \mathrm{C}$ & $\sim 60 \%$ & 30 hours +35 hours & II (second) stage \\
$24{ }^{\circ} \mathrm{C}$ & $>60 \%$ & 21 hours +16 hours & II (second) stage \\
\hline
\end{tabular}

*Based on the results in the research paper of Sorgeloos et al. (1978)

Furthermore, the larvae of I instar stage only consume their yolk as a food source and they are more resistant to positive control (chromic acid) due to their poorly developed epithelium of the digestive tract that disables the normal absorption of nutrients and toxic compounds from the external medium (Sorgeloos et al., 1978; Vanhacke and Persoone, 1984; Sleet and Brendel, 1985; Kokkali et al., 2011).

Therefore, even under given constant experimental temperature, salinity, light, pressure and $\mathrm{pH}$ conditions, the sensitivity of Artemia nauplii in different instar developmental stages differs markedly among different strains from different geographical regions.

\section{Preparation of the Brine Shrimp Assay}

The Brine Shrimp Lethality Assay has been developed for toxicity testing of various concentrations of pure compounds and crude plant extracts. Firstly, pure compounds and crude plant extracts were dissolved in a solvent suitable for the tested herbal sample. However, a mixture of several solvents may be a more suitable solvent system for some plant samples.

By dissolving the plant extract in a convenient solvent, a stock solution is made, which can be used for serial dilutions to prepare different concentrations. This is useful in the means of toxicity testing, because it is of high importance to determine the concentration range in which there is a linear correlation between the concentration and the lethality of the brine shrimps. Most experiments that involve the Brine Shrimp Lethality Assay for toxicity assessment of herbal extracts include a concentration range of 10, 100 and $1000 \mu \mathrm{g} / \mathrm{ml}$ (Parra et al., 2001).

The results for the toxicity of tested herbal preparations gained by using crude plant extracts were more accurate than by testing pure compounds isolated from the same plant. This difference in the toxicity results is probably due to the chemical complexity of the crude or partially purified extract, which seemed to be essential for the bioavailability of the active constituents of the examined plant. On the other hand, isolated pure compounds seemed to lose this specific bioactivity (Mayorga et al., 2010).

Prepared crude plant extracts in various concentrations can be tested by applying certain volume of the extract in vials containing brine solution or by applying the tested volume of extract on filter paper discs which are placed in vials afterwards (Meyer et al., 1982). Each vial contains the tested crude plant extract, artificial sea water and 10-15 brine shrimp nauplii. Ten nauplii were selected and transferred into each sample vial, and the final volume in each vial is adjusted with artificial seawater (Gadir, 2012). If there is no possibility to apply exact number of brine shrimps, all remaining alive nauplii are immobilized and the calculations could be made by counting the total number of dead shrimps in each vial (Pisutthanan et al., 2004; Ghisalberti, 1993).

Adding dry yeast suspension as food for the brine shrimps is optional (Gadir, 2012), because feeding the brine shrimps during the assay is insignificant when it comes to determining toxicity.

The negative control enables elimination of other factors that contribute to the total number of dead nauplii. The solvent used to dissolve the crude plant extracts is a relevant negative control for this purpose.

The toxicity of tested plant samples was determined by comparing their $\mathrm{LC}_{50}$ values with highly toxic substances suitable to be used as positive controls for this test, such as: vincristine sulphate (Ahmed et al., 2010), potassium dichromate (Naidu et al., 2014), thymol (Sharma et al., 2013; Mirzaei and Mirzaei, 2013), cyclophosphamide (Moshi et al., 2010), pure DMSO (Arlsanyolu and Erdemgil, 2006), caffeine (Gadir, 2012) etc.

\section{Data analysis}

Depending on the conditions of the experiment, survivors have been counted by magnifying glass or a microscope after certain period of time $(6,12,24,36,48,54$ and/ 
or 60 hours), although most toxicity studies which use the Brine Shrimp Assay determined the toxicity by counting the survived nauplii after 24 hours of exposure to the tested sample. Usually, no deaths were observed to occur in the negative control after 24 hours.

After 24 hours of exposure, the median lethal concentration $\left(\mathrm{LC}_{50}\right)$ of the test samples has been obtained by a plot of percentage of the shrimps killed against the logarithm of the sample concentration (Meyer et al., 1982; Ahmed et al., 2010; Moshi et al., 2010). LC $_{50}$ values were estimated using a probit regression analysis (Finney, 1971). Finney's statistical method (Table 2) was incorporated in several software packages such as Stata, MatLab, $\mathrm{R}$ and IBM SPSS, which enable computerized calculations of $\mathrm{LC}_{50}$ with confidence intervals (Fig.3). These calculations may not give the exact lethal concentration of the examined compound or extract that kills $50 \%$ of the population, but without doubt it represents a significant prelimi- nary data for further toxicity testing assays. In most studies, the experiment has been conducted in triplicate, so that gained results were statistically reproducible (Sharma et al., 2013; Pisutthanan et al., 2004; Parra et al., 2001).

\section{Toxicity testing criteria}

The toxicity of herbal extracts expressed as $\mathrm{LC}_{50}$ values is commonly valorized either by comparison to Meyer's or to Clarkson's toxicity index.

According to Meyer's toxicity index, extracts with $\mathrm{LC}_{50}<1000 \mu \mathrm{g} / \mathrm{ml}$ are considered as toxic, while extracts with $\mathrm{LC}_{50}>1000 \mu \mathrm{g} / \mathrm{ml}$ are considered as non-toxic (Meyer et al., 1982).

Clarkson's toxicity criterion for the toxicity assessment of plant extracts classifies extracts in the following order: extracts with $\mathrm{LC}_{50}$ above $1000 \mu \mathrm{g} / \mathrm{ml}$ are non-toxic, $\mathrm{LC}_{50}$ of

Table 2. Finney's table for transformation of percentage of mortality to probit values (Finney, 1952).

\begin{tabular}{ccccccccccc}
\hline \hline$\%$ & 0 & 1 & 2 & 3 & 4 & 5 & 6 & 7 & 8 & 9 \\
\hline 0 & $-\bar{y}$ & 2.67 & 2.95 & 3.12 & 3.25 & 3.36 & 3.45 & 3.52 & 3.59 & 3.66 \\
10 & 3.72 & 3.77 & 3.82 & 3.87 & 3.92 & 3.96 & 4.01 & 4.05 & 4.08 & 4.12 \\
20 & 4.16 & 4.19 & 4.23 & 4.26 & 4.25 & 4.33 & 4.36 & 4.39 & 4.42 & 4.45 \\
30 & 4.48 & 4.50 & 4.53 & 4.56 & 4.59 & 4.61 & 4.64 & 4.67 & 4.69 & 4.72 \\
40 & 4.75 & 4.77 & 4.80 & 4.82 & 4.85 & 4.87 & 4.90 & 4.92 & 4.95 & 4.97 \\
50 & 5.00 & 5.03 & 5.05 & 5.08 & 5.10 & 5.13 & 5.15 & 5.18 & 5.20 & 5.23 \\
60 & 5.25 & 5.28 & 5.31 & 5.33 & 5.36 & 5.39 & 5.41 & 5.44 & 5.47 & 5.50 \\
70 & 5.52 & 5.55 & 5.58 & 5.61 & 5.64 & 5.67 & 5.71 & 5.74 & 5.77 & 5.81 \\
80 & 5.84 & 5.88 & 5.92 & 5.95 & 5.99 & 6.04 & 6.08 & 6.13 & 6.18 & 6.23 \\
90 & 6.28 & 6.34 & 6.41 & 6.48 & 6.55 & 6.64 & 6.75 & 6.88 & 7.05 & 7.33 \\
& 0.0 & 0.1 & 0.2 & 0.3 & 0.4 & 0.5 & 0.6 & 0.7 & 0.8 & 0.9 \\
99 & 7.33 & 7.37 & 7.41 & 7.46 & 7.51 & 7.58 & 7.65 & 7.75 & 7.88 & 8.09 \\
\hline
\end{tabular}

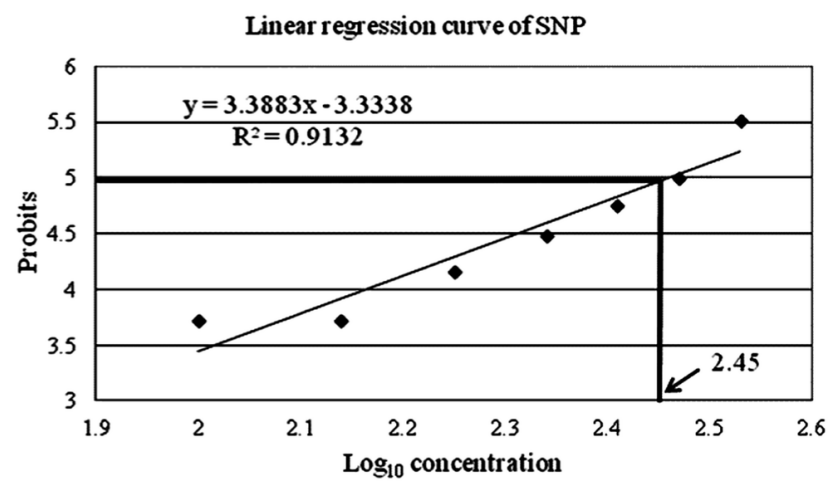

Fig. 3 Obtaining the logarithmic value of the concentration by interpolation from the linear correlation between probits and $\log (\mathrm{c})$ (Saha et al., 2014). 
$500-1000 \mu \mathrm{g} / \mathrm{ml}$ are low toxic, extracts with $\mathrm{LC}_{50}$ of 100 $500 \mu \mathrm{g} / \mathrm{ml}$ are medium toxic, while extracts with $\mathrm{LC}_{50}$ of 0 $100 \mu \mathrm{g} / \mathrm{ml}$ are highly toxic (Clarkson et al., 2004).

\section{Correlation between Brine Shrimp Assay and other animal models}

Due to the ethical issues in toxicological tests, substituting animals with alternative models is very important. The effectiveness of the Artemia salina bioassay for predicting the toxicity of plant extracts was evaluated by comparing the $\mathrm{LC}_{50}$ results for the brine shrimps with the $\mathrm{LD}_{50}$ results for acute toxicity in rats and mice (Sharma et al., 2013; Naidu et al., 2014; Parra et al., 2001).

Syahmi et al. have shown that $\mathrm{LC}_{50}$ values obtained by Brine Shrimp Lethality Assay are in good correlation with $\mathrm{LD}_{50}$ values obtained by examination of the acute toxicity of $E$. guineensis methanolic extracts using laboratory Swiss albino mice (Syahmi et al, 2010). Furthermore, using Sprague Dawley rats showed that $\mathrm{LD}_{50}$ values for the acute toxicity examined by oral route of Mentha spicata methanolic extract are significantly correlated with the $\mathrm{LC}_{50}$ results obtained by the Brine Shrimp Lethality Assay (Naidu et al., 2014). The $\mathrm{LD}_{50}$ values for the mice and rats models were above $5000 \mathrm{mg} / \mathrm{kg}$, and the $\mathrm{LC}_{50}$ values for the brine shrimps were above $1000 \mu \mathrm{g} / \mathrm{ml}$, indicating that these extracts are non-toxic.

It has been shown that a good correlation exists between the $\mathrm{LC}_{50}$ results obtained by force feeding female Sprague Dawley rats with a feeding needle of aqueous extracts of various plant species and the $\mathrm{LC}_{50}$ results obtained by 24 hour exposure of brine shrimps to those aqueous extracts. The $\mathrm{LC}_{50}$ results for the brine shrimps were above $5 \mathrm{mg} / \mathrm{ml}$,

Table 3. $\mathrm{LC}_{50}$ versus $\mathrm{LD}_{50}$ values in Brine Shrimp Lethality Assay and in vivo study - Swiss albino mice; toxicity classification according to Meyer's and Gosselin, Smith and Hodge's criteria

\begin{tabular}{|c|c|c|c|}
\hline Plant extract & $\begin{array}{l}\mathrm{LC}_{50}(\mathrm{Mg} / \mathrm{ml}) \text { obtained } \\
\text { by Brine Shrimp Lethali- } \\
\text { ty Assay }\end{array}$ & $\begin{array}{l}\mathrm{LD}_{50}(\mathrm{mg} / \mathrm{kg}) \text { obtained by } \\
\text { using Swiss albino mice } \\
\text { as experimental models }\end{array}$ & Toxicity class \\
\hline Aloe vera (L.) Burm. & 3.59 & 120.65 & Toxic/Very toxic \\
\hline Artemisia absinthium L. & 15.74 & 2499.10 & Toxic/Moderately toxic \\
\hline Citrus aurantium L. & 3.99 & 476.94 & Toxic/Very toxic \\
\hline $\begin{array}{l}\text { Cymbopogon citratus (DC. Ex Nees) } \\
\text { Stapf }\end{array}$ & 9.83 & 460.00 & Toxic/Very toxic \\
\hline Datura stramonium L. & 12.86 & 821.93 & Toxic/Moderately toxic \\
\hline Justicia pectoralis Jacq. & 60.14 & 3531.11 & Toxic/Moderately toxic \\
\hline Musa x paradisiaca $\mathrm{L}$. & 15.10 & 383.97 & Toxic/Very toxic \\
\hline Ocimum basilicum $\mathrm{L}$. & 9.92 & 956.50 & Toxic/Moderately toxic \\
\hline Ocimum gratissimum $\mathrm{L}$. & 18.76 & 2081.00 & Toxic/Moderately toxic \\
\hline Ocimum tenuiflorum $\mathrm{L}$. & 18.75 & 1540.00 & Toxic/Moderately toxic \\
\hline Orthosiphon aristatus (Blume) Miq. & 16.72 & 5026.31 & Toxic/Slightly toxic \\
\hline Pimenta dioica (L.) Merr. & 32.78 & 2560.00 & Toxic/Moderately toxic \\
\hline Piper auritum Kunth & 26.67 & 1802.00 & Toxic/Moderately toxic \\
\hline Plantago major $\mathrm{L}$. & 4.74 & 182.54 & Toxic/Very toxic \\
\hline $\begin{array}{l}\text { Plectranthus amboinicus (Lour.) } \\
\text { Spreng. }\end{array}$ & 52.29 & 4902.92 & Toxic/Moderately toxic \\
\hline $\begin{array}{l}\text { Plectranthus amboinicus (Lour.) } \\
\text { Spreng. Aqueous extract }\end{array}$ & 82.27 & 8193.00 & Toxic/Slightly toxic \\
\hline Ruta graveolens $\mathrm{L}$. & 5.39 & 219.45 & Toxic/Very toxic \\
\hline Senna alata (L.) Roxb. & 7.74 & 1459.32 & Toxic/Moderately toxic \\
\hline Stachytarpheta jamaicensis (L.) Valh & 14.51 & 2035.12 & Toxic/Moderately toxic \\
\hline Thuja occidentalis L. & 11.94 & 440.00 & Toxic/Very toxic \\
\hline
\end{tabular}

*according to Meyer's toxicity index for BSLA (Meyer et al., 1982)

**according to Gosselin, Smith and Hodge scale (Gosselin et al., 1984) 
and the results obtained for the acute oral toxicity in laboratory rats also indicated no evidence of toxicity. The results have shown that in both the brine shrimp and the laboratory animals there were no signs of acute toxicity (Shafii et al., 2011).

The cytotoxic effect of the bioactive compound Quassin present in different fractions of Quassia amara has been studied using Brine Shrimp Lethality Assay and experimental rats. From the examined fractions of this plant, the methanol fraction has shown the least toxic activity in brine shrimps, as well as in experimental rats which all survived after dosage with single limit test dose of $2000 \mathrm{mg} / \mathrm{kg}$ and $5000 \mathrm{mg} / \mathrm{kg}$ (Obembe et al., 2014).

A cytotoxicity study using Brine Shrimp Lethality Assay and Acute Oral Toxicity in Mice for the toxicity testing of Swietenia mahagoni (Linn.) seed methanol extract has shown that the plant is nontoxic. The $\mathrm{LC}_{50}$ results obtained for this plant extract using the Brine Shrimp Lethality Assay correspond to $\mathrm{LD}_{50}$ values between 2500 and $8000 \mathrm{mg} / \mathrm{kg}$ indicating that according to the Brine shrimp Lethality Assay it is nontoxic. The correlation between the $\mathrm{LC}_{50}$ results obtained by the BSLA and the $\mathrm{LD}_{50}$ results obtained in mice has been confirmed with the obtained $\mathrm{LD}_{50}$ values for mice above $5000 \mathrm{mg} / \mathrm{kg}$, meaning the plant is nontoxic for mice as well (Sahgal et al., 2010).

Parra et al. 2001 examined the toxicity effects of 20 plant extracts from different species using the Brine Shrimp Lethality Assay (BSLA) and in vivo studies with rats (Table 3).

The positive correlation between $\mathrm{LC}_{50}$ results obtained by the BSLA and $\mathrm{LD}_{50}$ results for in vivo animal models is confirmed by comparing the toxicity class of each plant extract according to Meyer's versus Gosselin, Smith and Hodge's toxicity scales (Table 3 ). The predicted oral $\mathrm{LD}_{50}$ dose for humans in Gosselin, Smith and Hodge's toxicity scale is based on the oral $\mathrm{LD}_{50}$ doses for rats as follows: less than $5 \mathrm{mg} / \mathrm{kg}$ is considered super toxic, $5-50 \mathrm{mg} / \mathrm{kg}$ is extremely toxic, $50-500 \mathrm{mg} / \mathrm{kg}$ is very toxic, $500-5000 \mathrm{mg} /$ $\mathrm{kg}$ is moderately toxic, $5000-15000 \mathrm{mg} / \mathrm{kg}$ is slightly toxic and above $15000 \mathrm{mg} / \mathrm{kg}$ is considered practically non-toxic (Gosselin et al., 1984).

This comparison confirmed that the Brine Shrimp Lethality Assay is an adequate method for preliminary toxicity testing in humans by using the brine shrimps as alternative model for the mice and rats in vivo models.

\section{Conclusion}

Many plant species possess pharmacologically active constituents which contribute to their wide use in folk medicine and in the design of drugs. On the other hand, many plants which have been described as being curative can also be associated with harmful effects. The concentration of a substance is the most important determinant of the outcome: if it reaches a sufficiently high concentration in the susceptible biological system, it could lead to toxic effects.
In order to gain relevant data which can be extrapolated to human population, it was of high need that in vivo testing using animal models was involved. For years, researchers have been using rats and other animal models that show a high correlation with the human population. Recently, this type of testing has been limited because of ethical and economic aspects. Therefore, alternative toxicity assays are widely used for the testing of the toxicity potential of plant products. Brine Shrimp Lethality Assay seemed like an appropriate solution, especially because it could still classify as in vivo testing. Artemia salina nauplii is one of the alternatives for the biological toxicity assays of herbal extracts, and this test turned out to be significantly correlated with several other animal models. The preliminary toxicity data obtained by conducting the Brine Shrimp Lethality Assay gives $\mathrm{LC}_{50}$ values which are a convenient platform for further toxicity studies.

\section{References}

Abubakar, M.G., Yerima, M. B., Zahriya, A. G., Ukwuani, A.N., 2010. Acute toxicity and antifungal studies of ethanolic leaves, stem and pulp extract of Tamarindus indica. Res J Pharm Biol Chem Sci. 1, 104-111.

Ahmed, A., Labu, Z.K., Dey, S.K., Hira, A., Howlader, M.S.I., Mohamed Hemayet Hossain, M.H., Roy, J., 2013. Phytochemical screening, antibacterial and cytotoxic activity of different fractions of Xylocarpus mekongensis Bark. Ibnosina J Med BS. 5, 206-213.

Ahmed, Y., Sohrab, H., Al-Reza, S.M., Shahidulla Tareq, F., Hasan, C.M., Sattar, M.A., 2010. Antimicrobial and cytotoxic constituents from leaves of Sapium baccatum. Food Chem Tox. 48, 549-552.

Arslanyolu, M., Erdemgil, F. Z., 2006. Evaluation of the antibacterial activity and toxicity of isolated arctiin from the seeds of Centaurea sclerolepis. J Fac Pharm. 35, 103-109.

Campbell, D.L., Lawton, L.A., Beattie, K.A., Codd, G.A., 1994. Comparative assessment of the specificity of the brine shrimp and microtox assays to hepatotoxic (microcystin-LRcontaining) cyanobacteria. Environ Tox. 9, 71-77.

Carballo, J.L., Hernández-Inda, Z.L., Pérez, P., García-Grávalos, M.D., 2002. A comparison between two brine shrimp assays to detect in vitro cytotoxicity in marine natural products. BMC Biotech. 2, 17.

Clarkson, C., Maharaj, V.J., Crouch, N.R., Grace, O.M., Pillay, P., Matsabisa, M. G., Bhagwandin, N., Smith, P.J., Folb, P.I., 2004. In vitro antiplasmodial activity of medicinal plants native to or naturalized in South Africa. J Ethnopharm. 92, 177-191.

Farnsworth, N.R., Soejarto, D.D. Global importance of medicinal plants, in: Akerele, O., Heywood, V., Synge, H., 2009. Conservation of medicinal plants, first ed. Cambridge University Press, Cambridge, pp. 25-52.

Finney, D., 1952. Probit analysis: a statistical treatment of the sigmoid response curve, Cambridge University Press, Cambridge.

Finney, D., 1971. Probit analysis, third ed. Cambridge University Press, Cambridge.

Gadir, S.A., 2012. Assessment of bioactivity of some Sudanese medicinal plants using Brine Shrimp (Artemia salina) Lethality Assay. J Chem Pharm Res. 4, 5145-5148. 
Ghisalberti, E.L. Detection and isolation of bioactive natural products, in: Colegate, S.M., Molyneux, R.J., 2007. Bioactive natural products: detection, isolation and structural determination, second ed. CRC Press, Florida, pp. 11-76.

Gosselin, R.E., Smith, R.P., Hodge, H.C., Braddock, J. 1984. Gosselin, Smith and Hodge toxicity scale. Retrieved from (http://www.ccohs.ca/oshanswers/chemicals/ld50.html) on 19/01/2015.

Jaki, B., Orjala, J., Sticher, O., 1999. A novel extracellular diterpenoid with antibacterial activity from the cyanobacterium Nostoc commune. J Nat Prod. 62, 502-503.

Kamba, A.S., Hassan, L.G., 2010. Antibacterial screening and Brine Shrimp (Artemia salina) toxicity over Securidaca longepedunculata (Polygalaceae) root bark. AJPSP. 1, 8595.

Kokkali, V., Katramados, I., Newman, J. D., 2011. Monitoring the effect of metal ions on the mobility of Artemia salina nauplii. Biosensors. 1, 36-45.

Lalisan, J.A., Nuñeza, O.M., Uy, M.M., 2014. Brine Shrimp (Artemia salina) Bioassay of the medicinal plant Pseudelephantopus spicatus from Iligan City, Philippines. Int Res J Biol Sci. 3, 47-50.

Martínez, M., Del Ramo, J., Torreblanca, A., Díaz-Mayans, J., 1999. Effect of cadmium exposure on zinc levels in the brine shrimp Artemia parthenogenetica. Aquaculture. 172, 315325.

Maurer-Jones, M.A., Love, S.A., Meierhofer, S., Marquis, B.J., Liu, Z., Haynes, C.L., 2013. Toxicity of nanoparticles to brine shrimp: An introduction to nanotoxicity and interdisciplinary science. J Chem Edu. 90, 475-478.

Mayorga, P., Pérez, K.R., Cruz, S.M., Cáceres, A., 2010. Comparison of bioassays using the anostracan crustaceans Artemia salina and Thamnocephalus platyurus for plant extract toxicity screening. Bras J Pharm. 20, 897-903.

McLaughlin, J.L., Rogers, L.L., Anderson, J.E., 1998. The use of biological assays to evaluate botanicals. Drug Inf J. 32, 513-524.

Meyer, B.N., Ferrigni, N.R., Putnam, J.E., Jacobsen, L.B., Nichols, D.E., McLaughlin, J.L., 1982. Brine Shrimp: A convenient general bioassay for active plant constituents. Planta Medica. 45, 31-34.

Michael, A.S., Thompson, C.G., Abramovitz, M., 1956. Artemia salina as a test-organism for bioassay. Sci. 123, 464.

Mirzaei, M., Mirzaei, A., 2013. Comparison of the Artemia salina and Artemia uramiana bioassays for toxicity of 4 Iranian medicinal plants. Int Res J Biol Sci. 2, 49-54.

Moshi, M.J., Innocent, E., Magadula, J.J., Otieno, D.F., Weisheit, A., Mbabazi, P.K., Nondo, R.S.O., 2010. Brine shrimp toxicity of some plants used as traditional medicines in Kagera Region, north western Tanzania. Tanz J H Res. 12, 63-67.

Musa, A.A., 2012. Cytotoxicity activity and phytochemical screening of Cochlospermum tinctorium Perr Ex A. rich rhizome. J of App Pharm Sci. 2, 155-159.

Naidu, J.R., Ismail, R., Sasidharan, S., 2014. Acute Oral Toxicity and Brine Shrimp Lethality of Methanol Extract of Mentha spicata L. (Lamiaceae). Trop J Pharm Res. 13, 101-107.

Obembe, O.O., Oloyede, G.K., Raji, Y., 2014. Cytotoxicity and Acute Oral Toxicity Study on Quassin and Fractions of Quassia amara Extract. IJSBAR. 13, 139-144.

Ogugu, S.E., Kehinde, A.J., James, B.I., Paul, D.K., 2012. Assessment of cytotoxic effects of methanol extract of Calliandra portoricensis using Brine Shrimp (Artemia salina) Lethality Bioassay. Glob J Bio-Sci Bitech. 2, 257260.

Olowa, L.F., Nuñeza, O.M., 2013. Brine Shrimp Lethality Assay of the ethanolic extracts of three selected species of medicinal plants from Iligan City, Philippines. Int Res J Biol Sci. 2, 74-77.

Parra, L.A., Yhebra, R.S., Sardiñas, I.G., Buela, L.I., 2001. Comparative study of the assay of Artemia salina L. and the estimate of the medium lethal dose $\left(\mathrm{LD}_{50}\right.$ value) in mice, to determine oral acute toxicity of plant extracts. Phytomed. 8, 395-400.

Pelka, M., Danzl, C., Distler, W., Petschelt, A., 2000. A new screening test for toxicity testing of dental materials. J Dent. 28, 341-345.

Pellosi, D.S., Batistela, V.R., Souza, V.R., Scarminio, I.S., Caetano, W., Hioka, N., 2013. Evaluation of the photodynamic activity of xanthene dyes on Artemia salina described by chemometric approaches. An Acad Bras Cienc. $85,1267-1274$

Pimentel Montanher, A.B., Pizzolatti, M.G., Costa Brighente, I.M., 2002. An Application of the Brine Shrimp Bioassay for general screening of Brazilian medicinal plants. Acta Farm. Bonaerense 21, 175-178.

Pisutthanan, S., Plianbangchang, P., Pisutthanan, N., Ruanruay, S., Muanrit, O., 2004. Brine shrimp lethality activity of Thai medicinal plants in the family Meliaceae. Naresuan Uni J. $12,13-18$

Ramachandran, S., Vamsikrishna, M., Gowthami, K.V., Heera, B., Dhanaraju, M.D., 2011. Assessment of cytotoxic activity of Agave cantula using Brine Shrimp (Artemia salina) Lethality Assay. Asian J of Sci Res. 4, 90-94.

Saha, S.K., Das, S., Chowdhury, P., Saha, Sa.K., 2014. Biocompatibility of a sonochemically synthesized poly(Nisopropyl acrylamide)/silica nanocomposite. RSC Adv. 4, 14457-14467.

Sahgal, G., Ramanathan, S., Sasidharan, S., Mordi, M.N., Ismail, S., Mansor, S.M., 2010. Brine Shrimp Lethality and Acute Oral Toxicity Studies on Swietenia mahagoni (Linn.) seed methanolic extract. Pharmacognosy Res. 2, 215-220.

Santos Pimenta, L.P., Pinto, G.B., Takahashi, J.A., Silva, L.G., Boaventura, M.A., 2003. Biological screening of annonaceous Brazilian medicinal plants using Artemia salina L. (Brine Shrimp Test). Phytomed. 10, 209-212.

Shafii, K., Fazliana, M.S., Shamsiah, A.R., 2011. Preliminary toxicology evaluation and heavy metal determination of selected Malaysian medicinal plants. Health and the Environment Journal. 2, 6-8.

Sharma, N., Gupta, P.C., Singh, A., Rao, C.V., 2013. Brine shrimp Bioassay of Pentapetes phoenicea Linn. and Ipomoea carnea jacq. leaves. Der Pharm Lett. 5, 162-167.

Sleet, R.B., Brendel, K., 1983. Improved methods for harvesting and counting synchronous population of Artemia nauplii for use in development toxicology. Ecotox Env Saf. 7, 435-446.

Sleet, R.B., Brendel, K., 1985. Homogeneous populations of Artemia nauplii and their potential use for in vitro testing in developmental toxicology. Teratog Carcinog Mutagen. 5, 41-44.

Solanki, S.S., Selvanayagam, M., 2013. Phytochemical screening and study of predictive toxicity of certain medicinal plants and extracts using brine shrimp. J Herb Sci Tech. 10, 1-4.

Sorgeloos, P., 1973. First report on the triggering effect of light on the hatching mechanism of Artemia salina dry cysts. Mar Biol. 22, 75-76. 
Sorgeloos, P., Remiche-Van Der Wielen, C., Persoone, G., 1978. The use of Artemia nauplii for toxicity tests - a critical analysis. Ecotox Env Saf. 2, 249-255.

Tülay, A.Ç., Özlem, S.A., 2007. Cytotoxic and genotoxic effects of Lavandula stoechas aqueous extracts. Biologia. 3, 292-296.

Vanhaecke, P., Persoone, G., 1984. The ARC-test: a standardized short-term routine toxicity test with Artemia nauplii. Methodology and evaluation. Ecotox test mar environ. 2, 588.

Vanhaecke, P., Persoone, G., Claus, C., Sorgeloos, P., 1981. Proposal for a short-term toxicity test with Artemia nauplii.
Ecotox Env Saf. 5, 382-387.

Veni, T., Pushpanathan, T., 2014. Comparison of the Artemia salina and Artemia fransiscana bioassays for toxicity of Indian medicinal plants. J Coastal Life Med. 2, 453-457.

World Health Organization. Department of Technical Cooperation for Essential Drugs and Traditional Medicine, 2007. Guidelines for assessing quality of herbal medicines with reference to contaminants and residues, World Health Organization, Geneva.

\title{
Токсиколошка евалуација на растителни производи со примена на модел со солени ракчиња (Artemia salina L.)
}

\author{
Ментор Р. Хамиди, Благица Јованова, Татјана Кадифкова Пановска* \\ Фармацевйски факулиетеи, Инсииииуй за ирименейа биохемија, Каиеера за иокксиколоіија, \\ Универзитетеи „Св. Кирил и Метиояиј“, Мајка Тереза 47, 1000 Скойје, Рейублика Макеоонија
}

Клучни зборови: тест за леталност на солени ракчиња, тестирање на токсичност, растителни екстракти, пробит анализа, $\mathrm{LC}_{50}$

Природните производи наоѓаат голема примена во развојот на нови лекови, поради бројните биолошки и фармаколошки својства кои ги поседуваат. Од друга страна, тие може да поседуваат и токсиколошки својства. Затоа, во терапијата со овие производи, податоци за безбедност се обезбедуваат преку бројни студии чија што главна цел на истражување се однесува на испитување на фармаколошките и на токсиколошките карактеристики. Овие студии истовремено се насочени и кон пронаоѓње на алтернативни биолошки тестови, од кои Тестот за леталност со солени ракчиња (Brine Shrimp Lethality Assay) се покажал како најсоодветен за оваа цел.

Овој метод дава можност за прелиминарна проценка на токсичноста на растителните екстракти, така што има многубројни предности, од кои што брзината, едноставноста и минималните услови за изведување на тестот се само дел од нив. Сепак, за да биде соодветна неговата примена во токсиколошки цели, потребна е стандардизација на експерименталните услови (температура, $\mathrm{pH}$ и концентрација на сол на медиумот, аерација и светлина).

Одредувањето на токсичноста на хербални екстракти со примена на овој метод е во концентрациски опсег од 10 , 100 и $1000 \mu \mathrm{g} / \mathrm{ml}$. Смртноста на ракчињата се определува најчесто после 24 часа експозиција, преку пресметување на средната летална концентрација $\left(\mathrm{LC}_{50}\right)$. Средната летална концентрација $\left(\mathrm{LC}_{50}\right)$ на испитуваните примероци се пресметува преку графички приказ на зависноста меѓу процентот на мртви ракчиња наспроти логаритамските вредности од соодветните концентрации на испитуваниот примерок и примена на пробит регресиона анализа. Потоа овие вредности се споредуваат со Мејер-овиот или Кларксон-овиот критериум за токсичност. Позитивната корелација помеѓу Мејеровата скала за токсичност на A. salina и Госелин, Смит, Хоџовата скала за токсичност за виши животински модели потврдува дека Тестот за леталност со солени ракчиња претставува одлична алатка за предвидување на токсичниот потенцијал на растителните екстракти кај луѓето. 